4

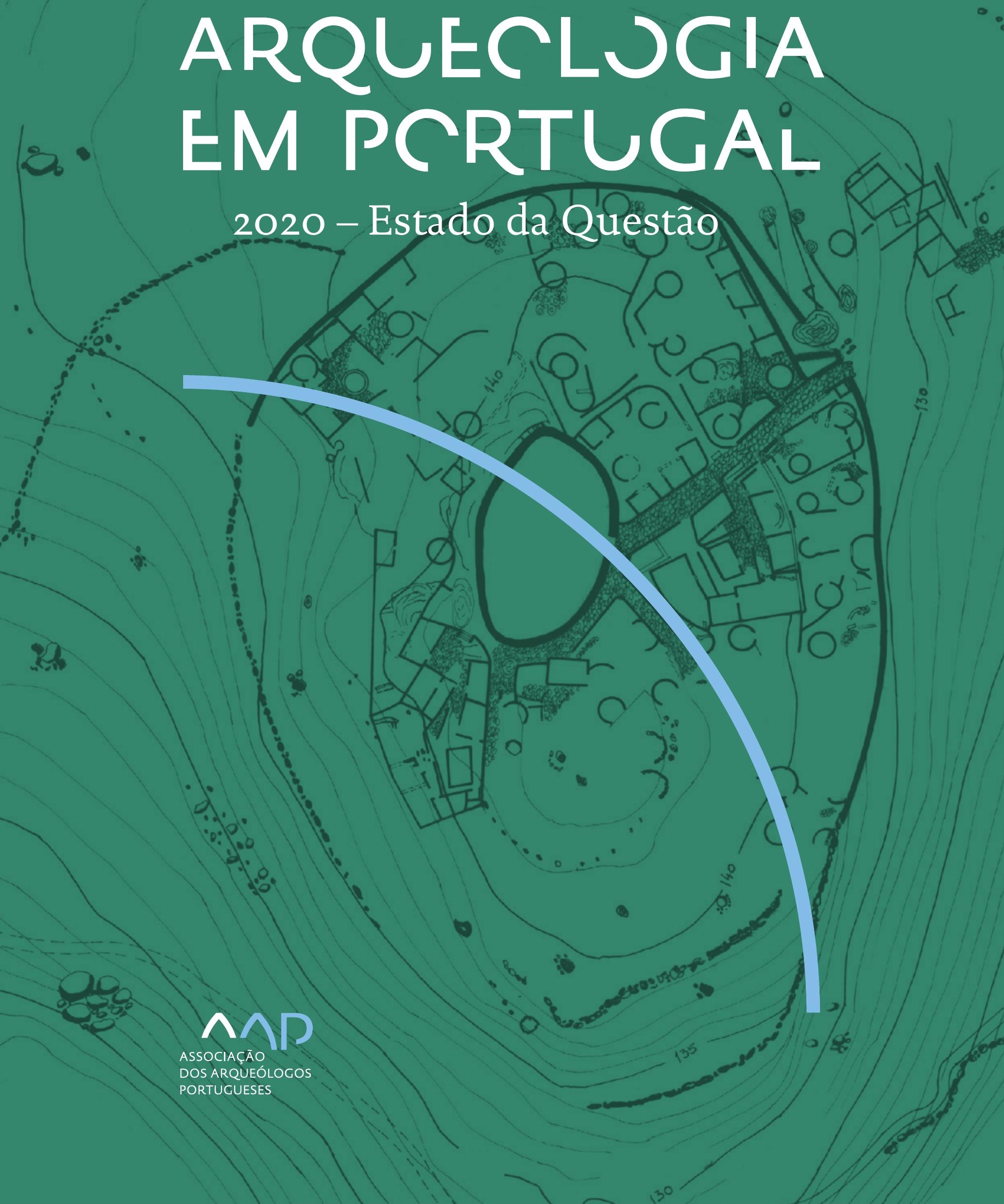


Coordenação editorial: José Morais Arnaud, César Neves e Andrea Martins Design gráfico: Flatland Design

AAP - ISBN: 978-972-9451-89-8

CITCEM - ISBN: 978-989-8970-25-1

Associação dos Arqueólogos Portugueses e CITCEM

Lisboa, 2020

O conteúdo dos artigos é da inteira responsabilidade dos autores. Sendo assim a Associação dos Arqueólogos Portugueses declina qualquer responsabilidade por eventuais equívocos ou questões de ordem ética e legal.

Desenho de capa:

Planta do castro de Monte Mozinho (Museu Municipal de Penafiel).

\section{$\hat{\wedge} \mathrm{P}$}

DOS ARQUEÓLOGOS PORTUGUESES

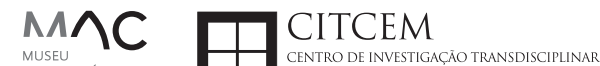
MUSEU
ARQUELLÓGICO
DO CARMO
U.PORTO

FLUP FACULDADE DE LETRAS
UNIVERSIDADE DO PORTO

Apoio

EC para a Ciência 


\section{Índice}

15 Prefácio

José Morais Arnaud

\section{Historiografia e Teoria}

17 Território, comunidade, memória e emoção: a contribuição da história da arqueologia (algumas primeiras e breves reflexões)

Ana Cristina Martins

25 Como descolonizar a arqueologia portuguesa?

Rui Gomes Coelho

41 Arqueologia e Modernidade: uma revisitação pessoal e breve de alguns aspetos da obra homónima de Julian Thomas de 2004

Vítor Oliveira Jorge

57 Dados para a História das Mulheres na Arqueologia portuguesa, dos finais do século XIX aos inícios do século XX: números, nomes e tabelas

Filipa Dimas / Mariana Diniz

73 Retractos da arqueologia portuguesa na imprensa: (in)visibilidades no feminino

Catarina Costeira / Elsa Luís

85 Arqueologia e Arqueólogos no Norte de Portugal Jacinta Bugalhão

101 Vieira Guimarães (1864-1939) e a arqueologia em Tomar: uma abordagem sobre o território e as gentes

João Amendoeira Peixoto / Ana Cristina Martins

115 Os memoráveis? A arqueologia algarvia na imprensa nacional e regional na presente centúria (2001-2019): características, visões do(s) passado(s) e a arqueologia

enquanto marca

Frederico Agosto / João Silva

129 A Evolução da Arqueologia Urbana e a Valorização Patrimonial no Barlavento Algarvio: Os casos de Portimão e Silves

Artur Mateus / Diogo Varandas / Rafael Boavida

\section{Gestão, Valorização e Salvaguarda do Património}

145 O Caderno Reivindicativo e as condições de trabalho em Arqueologia Miguel Rocha / Liliana Matias Carvalho / Regis Barbosa / Mauro Correia / Sara Simões / Jacinta Bugalhão / Sara Brito / Liliana Veríssimo Carvalho / Richard Peace / Pedro Peça / Cézer Santos

155 Os Estudos de Impacte Patrimonial como elemento para uma estratégia sustentável de minimização de impactes no âmbito de reconversões agrícolas Tiago do Pereiro

165 Salvaguarda de Património arqueológico em operações florestais: gestão e sensibilização Filipa Bragança / Gertrudes Zambujo / Sandra Lourenço / Belém Paiva / Carlos Banha / Frederico Tatá Regala / Helena Moura / Jacinta Bugalhão / João Marques / José Correia / Pedro Faria / Samuel Melro

179 Os valores do Património: uma investigação sobre os Sítios Pré-históricos de Arte Rupestre do Vale do Rio Côa e de Siega Verde José Paulo Francisco 
189 Conjugando recursos arqueológicos e naturais para potenciar as visitas ao Geoparque Litoral de Viana do Castelo (Noroeste de Portugal)

Hugo A. Sampaio / Ana M.S. Bettencourt / Susana Marinho / Ricardo Carvalhido

203 Áreas de Potencial Arqueológico na Região do Médio Tejo: Modelo Espacial Preditivo Rita Ferreira Anastácio / Ana Filipa Martins / Luiz Oosterbeek

223 Património Arqueológico e Gestão Territorial: O contributo da Arqueologia para a revisão do PDM de Avis

Ana Cristina Ribeiro

237 A coleção arqueológica do extinto Museu Municipal do Porto - Origens, Percursos e Estudos

Sónia Couto

251 Valpaços - uma nova carta arqueológica

Pedro Pereira / Maria de Fátima Casares Machado

263 Arqueologia na Cidade de Peniche

Adriano Constantino / Luís Rendeiro

273 Arqueologia Urbana: a cidade de Lagos como caso de Estudo Cátia Neto

285 Estratégias de promoção do património cultural subaquático nos Açores. O caso da ilha do Faial

José Luís Neto / José Bettencourt / Luís Borges / Pedro Parreira

297 Carta Arqueológica da Cidade Velha: Uma primeira abordagem

Jaylson Monteiro / Nireide Tavares / Sara da Veiga / Claudino Ramos / Edson Brito /

Carlos Carvalho / Francisco Moreira / Adalberto Tavares

311 Antropologia Virtual: novas metodologias para a análise morfológica e funcional Ricardo Miguel Godinho / Célia Gonçalves

\section{Didáctica da Arqueologia}

327 Como os projetos de Arqueologia podem contribuir para uma comunidade culturalmente mais consciente Alexandra Figueiredo / Claúdio Monteiro / Adolfo Silveira / Ricardo Lopes

337 Educação Patrimonial - Um cidadão esclarecido é um cidadão ativo! Ana Paula Almeida

351 A aproximação da Arqueologia à sala de aula: um caso de estudo no $3^{\circ}$ ciclo do Ensino Básico Luís Serrão Gil

363 Arqueologia 3.o - Pensar e comunicar a Arqueologia para um futuro sustentável Mónica Rolo

377 “Conversa de Arqueólogos" - Divulgar a Arqueologia em tempos de Pandemia Diogo Teixeira Dias

389 Escola Profissional de Arqueologia: desafios e oportunidades Susana Nunes / Dulcineia Pinto / Júlia Silva / Ana Mascarenhas

399 Os Museus de Arqueologia e os Jovens: a oferta educativa para o público adolescente Beatriz Correia Barata / Leonor Medeiros

411 O museu universitário como mediador entre a ciência e a sociedade: o exemplo da secção de arqueologia no Museu de História Natural e da Ciência da Universidade do Porto (MHNC-UP)

Rita Gaspar 
421 Museu de Lanifícios: Real Fábrica de Panos. Atividades no âmbito da Arqueologia Beatriz Correia Barata / Rita Salvado

427 Arqueologia Pública e o caso da localidade da Mata (Torres Novas) Cláudia Manso / Ana Rita Ferreira / Cristiana Ferreira / Vanessa Cardoso Antunes

431 Do sítio arqueológico ao museu: um percurso (também) didático Lídia Fernandes

447 Estão todos convidados para a Festa! E para dançar também... O projecto do Serviço Educativo do Museu Arqueológico do Carmo na $5^{\underline{a}}$ Edição da Festa da Arqueologia Rita Pires dos Santos

459 O “Clã de Carenque”, um projeto didático de arqueologia Eduardo Gonzalez Rocha

469 Mediação cultural: peixe que puxa carroça nas Ruínas Romanas de Troia Inês Vaz Pinto / Ana Patrícia Magalhães / Patrícia Brum / Filipa Santos

481 Didática Arqueológica, experiências do Projeto Mértola Vila Museu Maria de Fátima Palma / Clara Rodrigues / Susana Gómez / Lígia Rafael

\section{Arte Rupestre}

497 Os inventários de arte rupestre em Portugal Mila Simões de Abreu

513 O projeto FIRST-ART - conservação, documentação e gestão das primeiras manifestações de arte rupestre no Sudoeste da Península Ibérica: as grutas do Escoural e Maltravieso Sara Garcês / Hipólito Collado / José Julio García Arranz / Luiz Oosterbeek / António Carlos Silva / Pierluigi Rosina / Hugo Gomes / Anabela Borralheiro Pereira / George Nash / Esmeralda Gomes / Nelson Almeida / Carlos Carpetudo

523 Trabalhos de documentação de arte paleolítica realizados no âmbito do projeto PalæoCôa André Tomás Santos / António Fernando Barbosa / Luís Luís / Marcelo Silvestre / Thierry Aubry

537 Imagens fantasmagóricas, silhuetas elusivas: as figuras humanas na arte do Paleolítico Superior da região do Côa Mário Reis

$55^{1}$ Os motivos zoomórficos representados nas placas de tear de Vila Nova de São Pedro (Azambuja, Portugal) Andrea Martins / César Neves / José M. Arnaud / Mariana Diniz

571 Arte Rupestre do Monte de Góios (Lanhelas, Caminha). Síntese dos resultados dos trabalhos efectuados em 2007-2009 Mário Varela Gomes

599 Gravuras rupestres de barquiformes no Monte de S. Romão, Guimarães, Noroeste de Portugal Daniela Cardoso

613 Círculos segmentados gravados na Bacia do Rio Lima (Noroeste de Portugal): contributos para o seu estudo Diogo Marinho / Ana M.S. Bettencourt / Hugo Aluai Sampaio

631 Equídeos gravados no curso inferior do Rio Mouro, Monção (NW Portugal). Análise preliminar Coutinho, L.M. / Bettencourt, A.M.S / Sampaio, Hugo A.S

645 Paletas na Arte Rupestre do Noroeste de Portugal. Inventário preliminar Bruna Sousa Afonso / Ana M. S. Bettencourt / Hugo A. Sampaio 


\section{Pré-História}

661 O projeto Miño/Minho: balanço de quatro anos de trabalhos arqueológicos Sérgio Monteiro-Rodrigues / João Pedro Cunha-Ribeiro / Eduardo Méndez-Quintas / Carlos Ferreira / Pedro Xavier / José Meireles / Alberto Gomes / Manuel Santonja / Alfredo Pérez-González

677 A ocupação paleolítica da margem esquerda do Baixo Minho: a indústria lítica do sítio de Pedreiras 2 (Monção, Portugal) e a sua integração no contexto regional Carlos Ferreira / João Pedro Cunha-Ribeiro / Sérgio Monteiro-Rodrigues / Eduardo Méndez-Quintas / Pedro Xavier / José Meireles / Alberto Gomes / Manuel Santonja / Alfredo Pérez-González

693 O sítio acheulense do Plistocénico médio da Gruta da Aroeira Joan Daura / Montserrat Sanz / Filipa Rodrigues / Pedro Souto / João Zilhão

703 As sociedades neandertais no Barlavento algarvio: modelos preditivos com recurso aos SIG

Daniela Maio

715 A utilização de quartzo durante o Paleolítico Superior no território dos vales dos rios Vouga e Côa

Cristina Gameiro / Thierry Aubry / Bárbara Costa / Sérgio Gomes / Luís Luís / Carmen Manzano / André Tomás Santos

733 Uma perspetiva diacrónica da ocupação do concheiro do Cabeço da Amoreira (Muge, Portugal) a partir da tecnologia lítica Joana Belmiro / João Cascalheira / Célia Gonçalves

745 Novos dados sobre a Pré-história Antiga no concelho de Palmela. A intervenção arqueológica no sítio do Poceirão I

Michelle Teixeira Santos

757 Problemas em torno de Datas Absolutas Pré-Históricas no Norte do Alentejo Jorge de Oliveira

771 Povoamento pré-histórico nas áreas montanhosas do NO de Portugal: o Abrigo 1 de Vale de Cerdeira Pedro Xavier / José Meireles / Carlos Alves

783 Apreciação do povoamento do Neolítico Inicial na Baixa Bacia do Douro. A Lavra I (Serra da Aboboreira) como caso de estudo Maria de Jesus Sanches

797 O Processo de Neolitização na Plataforma do Mondego: os dados do Sector C do Outeiro dos Castelos de Beijós (Carregal do Sal)

João Carlos de Senna-Martinez / José Manuel Quintã Ventura / Andreia Carvalho / Cíntia Maurício

823 Novos trabalhos na Lapa da Bugalheira (Almonda, Torres Novas) Filipa Rodrigues / Pedro Souto / Artur Ferreira / Alexandre Varanda / Luís Gomes / Helena Gomes / João Zilhão

837 A pedra polida e afeiçoada do sítio do Neolítico médio da Moita do Ourives (Benavente, Portugal)

César Neves

857 Casal do Outeiro (Encarnação, Mafra): novos contributos para o conhecimento do povoamento do Neolítico final na Península de Lisboa.

Cátia Delicado / Carlos Maneira e Costa / Marta Miranda / Ana Catarina Sousa

873 Stresse infantil, morbilidade e mortalidade no sítio arqueológico do Neolítico Final/ Calcolítico ( $4^{\circ}$ e $3^{\circ}$ milénio a.C.) do Monte do Carrascal 2 (Ferreira do Alentejo, Beja) Liliana Matias de Carvalho / Sofia N. Wasterlain 
885 Come together: O Conjunto Megalítico das Motas (Monção, Viana do Castelo) e as expressões Campaniformes do Alto Minho Ana Catarina Basílio / Rui Ramos

899 Trabalhos arqueológicos no sítio Calcolítico da Pedreira do Poio Carla Magalhães / João Muralha / Mário Reis / António Batarda Fernandes

913 O sítio arqueológico de Castanheiro do Vento. Da arquitectura do sítio à arquitectura de um território João Muralha Cardoso

925 Estudo zooarqueológico das faunas do Calcolítico final de Vila Nova de São Pedro (Azambuja, Portugal): Campanhas de 2017 e 2018 Cleia Detry / Ana Catarina Francisco / Mariana Diniz / Andrea Martins / César Neves / José Morais Arnaud

943 As faunas depositadas no Museu Arqueológico do Carmo provenientes de Vila Nova de São Pedro (Azambuja): as campanhas de 1937 a 1967 Ana Catarina Francisco / Cleia Detry / César Neves / Andrea Martins / Mariana Diniz / José Morais Arnaud

959 Análise funcional de material lítico em sílex do castro de Vila Nova de S. Pedro (Azambuja, Portugal): uma primeira abordagem Rafael Lima

971 O recinto da Folha do Ouro 1 (Serpa) no contexto dos recintos de fossos calcolíticos alentejanos

António Carlos Valera / Tiago do Pereiro / Pedro Valério / António M. Monge Soares

\section{Proto-História}

987 Produção de sal marinho na Idade do Bronze do noroeste Português. Alguns dados para uma reflexão

Ana M. S. Bettencourt / Sara Luz / Nuno Oliveira / Pedro P. Simões / Maria Isabel C. Alves / Emílio Abad-Vidal

1001 A estátua-menir do Pedrão ou de São Bartolomeu do Mar (Esposende, noroeste de Portugal) no contexto arqueológico da fachada costeira de entre os rios Neiva e Cávado Ana M. S. Bettencourt / Manuel Santos-Estévez / Pedro Pimenta Simões / Luís Gonçalves

1015 O Castro do Muro (Vandoma/Baltar, Paredes) - notas para uma biografia de ocupação da Idade do Bronze à Idade Média

Maria Antónia D. Silva / Ana M. S. Bettencourt / António Manuel S. P. Silva / Natália Félix

1031 Do Bronze Final à Idade Média - continuidades e hiatos na ocupação de Povoados em Oliveira de Azeméis João Tiago Tavares / Adriaan de Man

1041 As faunas do final da Idade do Bronze no Sul de Portugal: leituras desde o Outeiro do Circo (Beja)

Nelson J. Almeida / Íris Dias / Cleia Detry / Eduardo Porfírio / Miguel Serra

1055 A Espada do Monte das Oliveiras (Serpa) - uma arma do Bronze Pleno do Sudoeste Rui M. G. Monge Soares / Pedro Valério / Mariana Nabais / António M. Monge Soares

1065 São Julião da Branca (Albergaria-a-Velha) - Investigação e valorização de um povoado do Bronze Final

António Manuel S. P. Silva / Paulo A. P. Lemos / Sara Almeida e Silva / Edite Martins de Sá

1083 Do castro de S. João ao Mosteiro de Santa Clara: notícia de uma intervenção arqueológica, em Vila do Conde Rui Pinheiro 
1095 O castro de Ovil (Espinho), um quarto de século de investigação - resultados e questões em aberto

Jorge Fernando Salvador / António Manuel S. P. Silva

1111 O Castro de Salreu (Estarreja), um povoado proto-histórico no litoral do Entre Douro e Vouga

Sara Almeida e Silva / António Manuel S. P. Silva / Paulo A. P. Lemos / Edite Martins de Sá

1127 Castro de Nossa Senhora das Necessidades (Sernancelhe): uma primeira análise artefactual Telma Susana O. Ribeiro

${ }_{1141}$ A cividade de Bagunte. O estado atual da investigação Pedro Brochado de Almeida

1153 Zoomorfos na cerâmica da Idade do Ferro no NW Peninsular: inventário, cronologias e significado Nuno Oliveira / Cristina Seoane

1163 Vasos gregos em Portugal: diferentes maneiras de contar a história do intercâmbio cultural na Idade do Ferro

Daniela Ferreira

1175 Os exotica da necrópole da Idade do Ferro do Olival do Senhor dos Mártires (Alcácer do Sal) no seu contexto regional

Francisco B. Gomes

\section{Antiguidade Clássica e Tardia}

1191 O uso de madeira como combustível no sítio da Quinta de Crestelos (Baixo Sabor): da Idade do Ferro à Romanização Filipe Vaz / João Tereso / Sérgio Simões Pereira / José Sastre / Javier Larrazabal Galarza / Susana Cosme / José António Pereira / Israel Espi

1207 Cultivos de Época Romana no Baixo Sabor: continuidade em tempos de mudança? João Pedro Tereso / Sérgio Simões Pereira / Filipe Santos / Luís Seabra / Filipe Vaz

1221 A casa romana na Hispânia: aplicação dos modelos itálicos nas províncias ibéricas Fernanda Magalhães / Diego Machado / Manuela Martins

1235 As pinturas murais romanas da Rua General Sousa Machado, n. ${ }^{5}$ 1, Chaves José Carvalho

1243 Trás do Castelo (Vale de Mir, Pegarinhos, Alijó) - Uma exploração agrícola romana do Douro

Tony Silvino / Pedro Pereira

1255 A sequência de ocupação no quadrante sudeste de Bracara Augusta: as transformações de uma unidade doméstica Lara Fernandes / Manuela Martins

1263 Os Mosaicos com decoração geométrica e geométrico-vegetalista dos sítios arqueológicos da área do Conuentus Bracaraugustanus. Novas abordagens quanto à conservação, restauro, decoração e datação Maria de Fátima Abraços / Licínia Wrench

1277 “Casa Romana” do Castro de São Domingos (Cristelos, Lousada): Escavação, Estudo e Musealização Paulo André de P. Lemos

1291 A arqueobotânica no Castro de Guifões (Matosinhos, Noroeste de Portugal): O primeiro estudo carpológico

Luís Seabra / Andreia Arezes / Catarina Magalhães / José Varela / João Pedro Tereso 
1305 Um Horreum Augustano na Foz do Douro (Monte do Castelo de Gaia, Vila Nova de Gaia) Rui Ramos

1311 Ponderais romanos na Lusitânia: padrões, formas, materiais e contextos de utilização Diego Barrios Rodríguez

1323 Um almofariz centro-itálico na foz do Mondego

Marco Penajoia

1335 Estruturas romanas de Carnide - Lisboa Luísa Batalha / Mário Monteiro / Guilherme Cardoso

1347 O contexto funerário do sector da "necrópole NO" da Rua das Portas de S. Antão (Lisboa): o espaço, os artefactos, os indivíduos e a sua interconectividade na interpretação do passado Sílvia Loja, José Carlos Quaresma, Nelson Cabaço, Marina Lourenço, Sílvia Casimiro, Rodrigo Banha da Silva, Francisca Alves-Cardoso

${ }_{1361}$ Povoamento em época Romana na Amadora - resultados de um projeto pluridisciplinar Gisela Encarnação / Vanessa Dias

1371 A Arquitectura Residencial em Mirobriga (Santiago do Cacém): contributo a partir de um estudo de caso Filipe Sousa / Catarina Felício

${ }_{1385}$ O fim do ciclo. Saneamento e gestão de resíduos nos edifícios termais de Mirobriga (Santiago do Cacém)

Catarina Felício / Filipe Sousa

1399 Balsa, Topografia e Urbanismo de uma Cidade Portuária Vítor Silva Dias / João Pedro Bernardes / Celso Candeias / Cristina Tété Garcia

1413 No Largo das Mouras Velhas em Faro (2017): novas evidências da necrópole norte de Ossonoba e da sua ocupação medieval Ricardo Costeira da Silva / Paulo Botelho / Fernando Santos / Liliana Nunes

1429 Instrumentos de pesca recuperados numa fábrica de salga em Ossonoba (Faro) Inês Rasteiro / Ricardo Costeira da Silva / Paulo Botelho

1439 A Necrópole Romana do Eirô, Duas Igrejas (Penafiel): intervenção arqueológica de 2016 Laura Sousa / Teresa Soeiro

1457 Ritual, descarte ou afetividade? A presença de Canis lupus familiaris na Necrópole Noroeste de Olisipo (Lisboa)

Beatriz Calapez Santos / Sofia Simões Pereira / Rodrigo Banha da Silva / Sílvia Casimiro / Cleia Detry / Francisca Alves Cardoso

1467 Dinâmicas económicas em Bracara na Antiguidade Tardia Diego Machado / Manuela Martins / Fernanda Magalhães / Natália Botica

1479 Cerâmicas e Vidros da Antiguidade Tardia do Edifício sob a Igreja do Bom Jesus (Vila Nova de Gaia) Joaquim Filipe Ramos

1493 Novos contributos para a topografia histórica de Mértola no período romano e na Antiguidade Tardia Virgílio Lopes

\section{8. Época Medieval}

1511 Cerâmicas islâmicas no Garb setentrional "português": algumas evidências e incógnitas Constança dos Santos / Helena Catarino / Susana Gómez / Maria José Gonçalves / Isabel Inácio / Gonçalo Lopes / Jacinta Bugalhão / Sandra Cavaco / Jaquelina Covaneiro / Isabel Cristina Fernandes / Ana Sofia Gomes 
1525 Contributo para o conhecimento da cosmética islâmica, em Silves, durante a Idade Média Rosa Varela Gomes

1537 Yábura e o seu território - uma análise histórico-arqueológica de Évora entre os séculos VIII-XII José Rui Santos

1547 A encosta sul do Castelo de Palmela - resultados preliminares da escavação arqueológica Luís Filipe Pereira / Michelle Teixeira Santos

1559 A igreja de São Lourenço (Mouraria, Lisboa): um conjunto de silos e de cerâmica medieval islâmica

Andreia Filipa Moreira Rodrigues

1571 O registo material de movimentações populacionais no Médio Tejo, durante os séculos XII-XIII. Dois casos de "sunken featured buildings", nos concelhos de Cartaxo e Torres Novas Marco Liberato / Helena Santos / Nuno Santos

1585 O nordeste transmontano nos alvores da Idade média. Notas para reflexão Ana Maria da Costa Oliveira

1601 Sepulturas escavadas na rocha do Norte de Portugal e do Vale do Douro: primeiros resultados do Projecto SER-NPVD

Mário Jorge Barroca / César Guedes / Andreia Arezes / Ana Maria Oliveira

1619 "Portucalem Castrum Novum" entre o Mediterrâneo e o Atlântico: o estudo dos materiais cerâmicos alto-medievais do arqueossítio da rua de D. Hugo, nํ. 5 (Porto) João Luís Veloso

1627 A Alta Idade Média na fronteira de Lafões: notas preliminares sobre a Arqueologia no Concelho de Vouzela

Manuel Luís Real / Catarina Tente

1641 Um conjunto cerâmico medieval fora de portas: um breve testemunho aveirense Susana Temudo

${ }_{1651}$ Os Lóios do Porto: uma perspetiva integrada no panorama funerário da Baixa Idade Média à Época Moderna em meios urbanos em Portugal

Ana Lema Seabra

1659 O Caminho Português Interior de Santiago como eixo viário na Idade Média Pedro Azevedo

1665 Morfologia Urbana: Um exercício em torno do Castelo de Ourém André Donas-Botto / Jaqueline Pereira

1677 Intervenção arqueológica na Rua Marquês de Pombal/Largo do Espírito Santo (Bucelas, Loures)

Florbela Estêvão / Nathalie Antunes-Ferreira / Dário Ramos Neves / Inês Lisboa

1691 O Cemitério Medieval do Poço do Borratém e a espacialidade funerária na cidade de Lisboa Inês Belém / Vanessa Filipe / Vasco Noronha Vieira / Sónia Ferro / Rodrigo Banha da Silva

1705 Um Espaço Funerário Conventual do séc. XV em Lisboa: o caso do Convento de São Domingos da Cidade Sérgio Pedroso / Sílvia Casimiro / Rodrigo Banha da Silva / Francisca Alves Cardoso

\section{9. Época Moderna e Contemporânea}

1721 Arqueologia Moderna em Portugal: algumas reflexões críticas em torno da quantificação de conjuntos cerâmicos e suas inferências históricas e antropológicas Rodrigo Banha da Silva / André Bargão / Sara da Cruz Ferreira

1733 Faianças de dois contextos entre os finais do século XVI e XVIII do Palácio dos Condes de Penafiel, Lisboa

Martim Lopes / Tomás Mesquita 
1747 Um perfil de consumo do século XVIII na foz do Tejo: O caso do Mercado da Ribeira, Lisboa Sara da Cruz Ferreira / Rodrigo Banha da Silva / André Bargão

1761 Os Cachimbos dos Séculos XVII e XVIII do Palácio Mesquitela e Convento dos Inglesinhos (Lisboa)

Inês Simão / Marina Pinto / João Pimenta / Sara da Cruz Ferreira / André Bargão / Rodrigo Banha da Silva

1775 "Tomar os fumos da erua que chamão em Portugal erua sancta». Estudo de Cachimbos provenientes da Rua do Terreiro do Trigo, Lisboa

Miguel Martins de Sousa / José Pedro Henriques / Vanessa Galiza Filipe

1787 Cachimbos de Barro Caulínitico da Sé da Cidade Velha (República de Cabo Verde)

Rodrigo Banha da Silva / João Pimenta / Clementino Amaro

1801 Algumas considerações sobre espólio não cerâmico recuperado no Largo de Jesus (Lisboa) Carlos Boavida

1815 Adereços de vidro, dos séculos XVI-XVIII, procedentes do antigo Convento de Santana de Lisboa (anéis, braceletes e contas)

Joana Gonçalves / Rosa Varela Gomes / Mário Varela Gomes

1837 Da ostentação, luxo e poder à simplicidade do uso quotidiano: arqueologia e simbologia de joias e adornos da Idade Moderna Portuguesa Jéssica Iglésias

1849 Os amuletos em Portugal - dos objetos às superstições: o coral vermelho Alexandra Vieira

1865 Cerâmicas de Vila Franca de Xira nos séculos XV e XVI Eva Pires

1879 «Não passa por teu o que me pertence». Marcas de individualização associadas a faianças do Convento de Nossa Senhora de Aracoeli, Alcácer do Sal Catarina Parreira / Íris Fragoso / Miguel Martins de Sousa

1891 Cerâmica de Leiria: alguns focos de produção

Jaqueline Pereira / André Donas-Botto

1901 Os Fornos na Rua da Biquinha, em Óbidos Hugo Silva / Filipe Oliveira

1909 A casa de Pêro Fernandes, contador dos contos de D. Manuel I: o sítio arqueológico da Silha do Alferes, Seixal (século XVI) Mariana Nunes Ferreira

1921 O Alto da Vigia (Sintra) e a vigilância e defesa da costa Alexandre Gonçalves / Sandra Santos

1937 O contexto da torre sineira da Igreja de Santa Maria de Loures Paulo Calaveira / Martim Lopes

1949 A Necrópole do Hospital Militar do Castelo de São Jorge e as práticas funerárias na Lisboa de Época Moderna Susana Henriques / Liliana Matias de Carvalho / Ana Amarante / Sofia N. Wasterlain

1963 SAND - Sarilhos Grandes Entre dois Mundos: o adro da Igreja e a Paleobiologia dos ossos humanos recuperados

Paula Alves Pereira / Roger Lee Jesus / Bruno M. Magalhães

1975 Expansão urbana da vila de Cascais no século XVII e XVIII: a intervenção arqueológica na Rua da Vitória no 15 a 17

Tiago Pereira / Vanessa Filipe

1987 Novos dados para o conhecimento do Urbanismo de Faro em época Moderna Ana Rosa 
1995 Um exemplo de Arqueologia Urbana em Alcoutim: o Antigo Edifício dos CTT Marco Fernandes / Marta Dias / Alexandra Gradim / Virgílio Lopes / Susana Gómez Martínez

2007 Palácio dos Ferrazes (Rua das Flores/Rua da Vitória, Porto): a cocheira de Domingos Oliveira Maia

Francisco Raimundo

2021 As muitas vidas de um edifício urbano: História, Arqueologia e Antropologia no antigo Recreatório Paroquial de Penafiel Helena Bernardo / Jorge Sampaio / Marta Borges

2035 O convento de Nossa Senhora da Esperança de Ponta Delgada: o contributo da arqueologia para o conhecimento de um monumento identitário João Gonçalves Araújo / N’Zinga Oliveira

2047 Arqueologia na ilha do Corvo... em busca da capela de Nossa Senhora do Rosário Tânia Manuel Casimiro / José Luís Neto / Luís Borges / Pedro Parreira

2059 Perdidos à vista da Costa. Trabalhos arqueológicos subaquáticos na Barra do Tejo Jorge Freire / José Bettencourt / Augusto Salgado

2071 Arqueologia marítima em Cabo Verde: enquadramento e primeiros resultados do projecto CONCHA

José Bettencourt / Adilson Dias / Carlos Lima / Christelle Chouzenoux / Cristóvão Fonseca / Dúnia Pereira / Gonçalo Lopes / Inês Coelho / Jaylson Monteiro / José Lima / Maria Eugénia Alves / Patrícia Carvalho / Tiago Silva

2085 Trabalhos arqueológicos na Cidade Velha (Ribeira Grande de Santiago, Cabo Verde): reflexões sobre um projecto de investigação e divulgação patrimonial André Teixeira / Jaylson Monteiro / Mariana Mateus / Nireide Tavares / Cristovão Fonseca / Gonçalo C. Lopes / Joana Bento Torres / Dúnia Pereira / André Bargão / Aurélie Mayer / Bruno Zélie / Carlos Lima / Christelle Chouzenoux / Inês Henriques / Inês Pinto Coelho / José Lima / Patrícia Carvalho / Tiago Silva

2103 A antiga fortificação de Quelba / Khor Kalba (E.A.U.). Resultados de quatro campanhas de escavações, problemáticas e perspectivas futuras Rui Carita / Rosa Varela Gomes / Mário Varela Gomes / Kamyar Kamyad

2123 Colónias para homens novos: arqueologia da colonização agrária fascista no noroeste ibérico Xurxo Ayán Vila / José Mạ . Señorán Martín 


\title{
DA OSTENTAÇÃO, LUXO E PODER À SIMPLICIDADE DO USO QUOTIDIANO: ARQUEOLOGIA E SIMBOLOGIA DE JOIAS E ADORNOS DA IDADE MODERNA PORTUGUESA
}

\author{
Jéssica Alexandra Martins Teixeira Iglésias ${ }^{1}$
}

\begin{abstract}
RESUMO
Ao longo dos séculos e pelo mundo, as joias e os objetos de adorno pessoais, desde sempre fascinaram o ser humano. Estes objetos passaram a ser usados como uma demonstração pública de riqueza cultural, pessoal, e do gosto próprio do seu utilizador tanto em vida como na morte.

Neste sentido o uso destes objetos durante os séculos XIV-XVIII, elaborados em diversas matérias primas, proporcionaram o surgimento e criação de elementos híbridos, que em grande medida foram consequentes de influências provocadas pela experiência ultramarina portuguesa, e pelas transformações sofridas nos gostos e modas europeias que contribuíram para a criação de uma nova sociedade, que continuou a acreditar nos valores apotropaicos e profiláticos de matérias-primas absorvendo novas crenças resultantes dos contactos com novas culturas.

Palavras-chave: Joias, Adornos, Idade Moderna; Cultura Material, Simbologia.
\end{abstract}

\begin{abstract}
Over the centuries and around the world, jewelry and personal adornments have always fascinated the human being. These objects came to be used as a public demonstration of cultural, personal wealth, and the user's own taste both in life and in death.

In this sense, the use of these objects during the $14^{\text {th }}-18^{\text {th }}$ centuries, made of different raw materials, provided the appearance and creation of hybrid elements, which were largely the result of influences caused by the Portuguese overseas experience, and by the changes undergone in tastes and fashions. Europeans who contributed to the creation of a new society, who continued to believe in the apotropaic and prophylactic values of raw materials absorbing new beliefs resulting from contacts with new cultures.
\end{abstract}

Keywords: Jewels, Adornments, Modern Age, Material Culture, Symbolism.

\section{INTRODUÇÃO}

A cultura material produzida por uma sociedade é fundamental para a compreensão da sua evolução e sucessivas transformações, e tal como outos elementos profusamente analisados, a joalharia e adornos também possibilitam a compreensão dos nossos ancestrais e da sua sociedade, entrar nas suas casas e compreender o seu modo de vida, entender os seus sentimentos, pensamentos e crenças. Contudo estes materiais, tratam-se de um registo arqueológico muito particular e frequentemente mal interpretado, o que regularmente conduz erroneamente à sua associação a uma cultura material pouco expressiva. Para além desta problemática, podemos adicionar o facto destes objetos apresentarem dois valores 
distintos, por um lado o económico, pois foram elaborados com metais e matérias de grande valor comercial, e consequentemente um grande alvo de colecionismo e venda. Por outro lado, a possibilidade de fundição dos seus metais e extração de pedrarias para a formação de novas peças, conferindo-lhes um design que fosse de encontro à moda do período em questão, permitindo assim a sua reciclagem e menores gastos face à aquisição de novas peças.

Neste sentido, "fausto" e "exotismo" são os termos que melhor descrevem a sociedade portuguesa no auge das conquistas e descobertas ultramarinas, com eles uma onda de mercadorias exóticas e objetos "curiosos" inundam e transformam o quotidiano. Consequentemente este intercâmbio cultural e lucrativo comércio acabou por invadir e influenciar todos as esferas da sociedade portuguesa desde o mais humilde dos cidadãos, aos membros religiosos até às elites.

Estas novas matérias primas surgem identificadas na documentação como sendo portadoras de propriedades medicinais e mágicas, contudo estas caraterísticas sobrenaturais são em grande parte herdadas da Idade Média, resgatadas durante a Idade Moderna e aliadas às tradições dos seus locais de origem. Apesar da forte religiosidade cristã, a necessidade de proteção e consequentemente a utilização de amuletos não se alterou, o que permitiu a integração e readaptação destas crenças e simbologias a esta religião ${ }^{2}$ (TAIT, 1996, p. 207).

Assim o significado e utilização de elementos de adorno é muito mais complexo do que esta simples equação de joias versus poder pode sugerir, as joias tornam-se um reflexo de gosto pessoal, arte, riqueza, investimento de capital e em alguns casos mnemónica para acontecimentos, individualidades ou grupos coletivos.

\section{ADORNOS DE CABELO}

Os adornos de cabelo e aplicação destes objetos como elementos decorativos ou rituais no tratamento e higiene do cabelo, foi de grande importância desde tempos mais remotos, em vida, na morte, identida-

2. Exemplo deste fator é a crença de que algumas pedras teriam virtudes religiosas como por exemplo "the contemplation of the deep blue of the sapphire could raise men's souls to the contemplation of heavenly kingdom". (TAIT, 1996, p. 207). de, inclusão ou exclusão social, ambientes estes que tendem a ser realizados em privado e consequentemente mais difícil de ser vistos no registo arqueológico e históricos. Estes elementos encontram-se simbolicamente associados ao sexo e sexualidade, à existência de espíritos e propriedades mágicas, à ideia de personalidade e representação de vitalidade do seu proprietário (ASHBY, 2014, p. 159).

Neste sentido, o cabelo e o seu enfeite, seriam uma mais valia na transmissão de poder social, político, económico, militar, demonstração de estatuto social, idade, género, religião, diferenciação étnica e em última instância cultivo da beleza, pois é um elemento facilmente visível, acessível e manipulável pelo seu usuário (ASHBY, 2014, p. 170).

No caso dos pentes e travessas, os adornos de cabelo que comummente surgem em contexto arqueológico, teriam como função primária a higiene e confeção de penteados, contudo não deve ser desmerecida a sua utilização como elemento de adorno e elemento apotropaico, ligado à força vital do cabelo e transformação da aparência, devendo-se em parte, às pontas aguçadas dos seus dentes capaz de repelir o mau olhado e até mesmo doenças, o que promoveu a sua utilização não só como ornamento, mas também pendurado ao pescoço (GOMES, 2010, p. 356). Contudo, não é fiável assumir que teriam sido usados exclusivamente com a função de pentear o cabelo humano, também poderiam ser utilizados como elemento de higiene contra a redução de pragas de piolhos, ou para a preparação de barbas e bigodes. Para além destas utilizações é de ressaltar a possibilidade de aplicação destes objetos em diversas outras áreas, sendo de destacar o alinho do pelo de animais domésticos, na preparação de fibras animais e vegetais para a produção têxtil, em ambientes rituais, como decoração ou como suporte a complexos arranjos de cabelo (GOMES, 2010, p. 356).

É ainda de ressaltar que o aparecimento destes materiais em contexto funerário poderá estar conotado com um simbolismo religioso de limpeza e purificação do corpo, como metáfora para a final transformação do corpo humano ou com a sua utilização na vida post-mortem, com o interesse em demonstrar que em vida o indivíduo teve acesso e apreço por este tipo de materiais e tecnologias.

Nas escavações realizadas na Igreja de Nossa Senhora da Esperança do Convento de São Francisco de Castelo de Vide, foram coletados treze pentes ou travessas (Figura 1. a, b, c, d, e, f) provenientes 
de oito sepulturas junto ao altar, algumas das quais ainda apresentavam, nas suas tampas, epigrafe com o nome de família e seus herdeiros. Apesar de não ter sido possível realizar a diagnose sexual nestes casos, os elementos em questão foram recolhidos em indivíduos adultos e associados com fragmentos de cerâmica de cozinha, faianças, alfinetes de mortalha, objetos de vestuário (botões, fivelas) e anéis (SANTOS S. , 2010, p. 8), o que demonstra um elevado poder social e económico dos inumados, não só devido ao posicionamento das suas sepulturas, mas também pelo facto de todos os elementos serem produzidos em carapaça de tartaruga, matéria-prima de importação. Dos treze elementos, apenas três possuem decoração incisa com linhas horizontais. Para além deste fator, apenas um elemento (Figura 1.c) apresentava um dente polido, o que poderá indicar uma contínua utilização, talvez até por várias gerações, o que implicaria o seu uso mesmo danificado, tanto pelo seu simbolismo sentimental como pelo do próprio objeto.

Elementos semelhantes poderão ser visualizados em utilização em pinturas dos séculos XVIII e XIX, tais como Margaret Sarah Carpenter, de autor desconhecido ou Head of a Woman, de Alfred Wadsworth.

Outra classe de adornos capilares utilizados no início da modernidade foram os toucados, elementos estes com algumas reminiscências medievais. Um exemplar destes objetos surge em escavações realizadas na Igreja de Santa Maria de Sabonha (Alcochete) (Figura 1. g) proveniente de um enterramento feminino datado do século XVI. Para além do toucado in situ preso por cinco alfinetes, no esqueleto ainda foram recuperados um fino anel de vidro preto na mão direita e entre as mãos um rosário em osso e fibras vegetais (CORREIA, 2005, pp. 10-12). O local de enterramento e os adornos recolhidos permitem determinar que a inumada, teria um elevado estatuto social e algum poder económico, pois os materiais recolhidos, apesar de não serem confecionados em matérias preciosas, claramente marcam a necessidade de demonstrar um certo estatuto social e capital monetário acumulado em vida.

O estilo de adorno de cabeça é um claro exemplar documentado na iconografia dos séculos XV e XVI, o que confirma claramente a datação do século XVI apresentada, tais como Portrait of a Lady de Giovanni Predis ou Eleonora di Toledo, de Agnolo Bronzino. Para além dos pentes, travessas e toucados, podemos acrescentar aos elementos de adornos de Idade
Moderna as bandoletes. Um exemplar metálico surge in situ na Igreja do Convento de Nossa Senhora da Conceição de Almodôvar, na zona frontal do crânio, juntamente com fragmentos de um tecido fino, provavelmente pertencente a um véu. Este estilo de adorno capilar poderá ser semelhante ao elemento apresentado num retrato de Maria Madalena, de Ambrosius Benson. Esta figura feminina ostenta um véu translúcido preso, pelo que poderemos supor ser uma bandolete metálica.

Elemento semelhante porem em carapaça de tartaruga, emerge nas escavações do Convento de Santana de Lisboa, em contexto de descarte juntamente com alguns pentes ou travessas. Estes elementos pertenceram a uma comunidade religiosa feminina, que ocupou o espaço durante os séculos XVII e XVIII, cronologia a que pertence a maioria do espólio ali exumado (GOMES , GOMES , \& GONÇALVES, 2017, pp. 102-103).

Como vimos anteriormente, a utilização de casco de tartaruga em adornos de cabelo é particularmente frequente, devido às suas origens exógenas, propriedades apotropaicos, associação simbológica à fecundidade, imortalidade, longevidade, conhecimento e sabedoria e facilidade de trabalho, foi considerada um material semiprecioso na Europa medieval e Moderna sendo que as mais apreciadas nestes períodos provinham das Maldivas e Filipinas. As propriedades curativas destes animais foram tão afamadas que o rei francês Luís XI promoveu uma expedição a Cabo Verde, tendo em vista averiguar estas curas milagrosas, pois suspeitava que padecia de lepra (LOUREIRO \& TORRÃO, 2008, p. 50).

\section{ANÉIS}

Desde os tempos pré-históricos que o homem utiliza estes elementos como símbolos de adorno, poder, autoridade, riqueza, de identidade individual e coletiva, nas suas mais variadas formas e infinidade de materiais, alguns deles considerados como tendo propriedades mágicas e protetoras, para além de realçarem a beleza, elegância e personalidade dos seus utilizadores, estes poderiam ser usados em qualquer dedo das mãos de acordo com gostos, modas e evitando a penetração de más energias.

Devido à sua forma circular, os anéis podem ser associados a um movimento de continuidade, eternidade, sendo capazes de reter indeterminadamente os maus espíritos e assim proteger e trazer boa sorte 
aos seus usuários. Para além destes elementos, os anéis também poderão ser associados à perfeição, união e compromisso, daí a tradição de troca de anéis durante a cerimónia matrimonial como associação à eternidade, cumplicidade e amor eterno (ROOP, 2011, pp. 2-11).

Para além desta simbologia, também poderão ser relacionados aos genitais femininos, numa clara alusão ao ato sexual.

As escavações realizadas no Edifício das cavalariças do Castelo de Castelo de Vide, possibilitaram a recolha de um anel que apresenta um "V" grosseiramente gravado (Figura 2.a), provavelmente realizado após a sua produção. Este tipo de ação não é rara em objetos de joalharia, pois reforçam a ideia de posse e pertença do elemento a um determinado individuo. Um inventário realizado após a morte de Lourenço de Medici em 1492, lista a posse de setenta e seis gemas preciosas das quais quarenta e duas apresentam o seu nome ou iniciais gravadas expondo claramente a ideia de posse e importância de demonstração da sua riqueza através da associação do seu nome (SESSIN, 2014, p. 14).

O modelo deste anel é muito semelhante a elementos exumados em liga de cobre nas escavações de uma antiga colónia espanhola, La Isabela, localizada na atual República Dominicana, estes anéis foram considerados como estando em utilização durante o século $\mathrm{XV}$, pois a ocupação do assentamento foi muito breve (1493-1496) (DEAGAN, 2002, p. 83). Neste sentido podemos pressupor que o elemento em estudo, provavelmente esteve em utilização durante os séculos XIV e XV, tal como outros elementos de adorno, os seus modelos permaneceram em voga durante um largo período de tempo.

Seguindo esta ideia de joias enquanto elementos de demostração e posse, poderemos integrar os anéis sinete, simbolicamente estes elementos pretendiam autentificar qualquer documento, representar, substituir, identificar ou completar a imagem e personalidade do seu possuidor. Exemplo destes elementos é um anel metálico banhado a dourado recolhido nos trabalhos do Castelo de Torres Vedras (Figura 2.b) este exumado num contexto de lixeira do século XVI-XVII, apresenta na zona central um monograma com a letra "N".

Estes elementos de adorno também poderiam representar o poder político, militar ou religioso do seu usuário como é exemplo de dois achados na Sinagoga de Castelo de Vide, um dos anéis em vidro negro apresentava como decoração uma cartela circular com cinco círculos em relevo (Figura 2.c), este elemento é semelhante a um recolhido no assentamento espanhol San Luis de Talimali na Flórida (1650-1700), (DEAGAN, 2002, p. 124). A representação de cinco elementos poderá estar relacionada com a simbologia cristã das cinco chagas de Cristo ou à estrela de cinco pontas de do rei David. Em ambos os casos estes elementos têm claramente conotação apotropaica e de identidade religiosa.

Para além deste elemento vítreo do mesmo sítio arqueológico português surge um anel que parece exibir uma cruz florenciada (Figura 2.d) provavelmente uma insígnia da ordem militar de Avis. Esta ordem parece não ser rara em Castelo de Vide, pois nas escavações realizadas na Igreja de Nossa Senhora da Esperança do Convento de São Francisco de Castelo de Vide foi recolhida uma insígnia militar (Figura 2.e) com a mesma decoração, como suspensão ostentava um laço ou laça, esta tipologia de elementos decorativos popularizou-se durante os século XVII-XVIII. As cruzes e insígnia apresentadas são muito semelhantes a uma divisa militar patente no Palácio Nacional da Ajuda, na qual são ostentadas em pedrarias a ordem de Cristo, Santiago e Avis.

Também nestes séculos visualizamos o surgimento do costume de utilização de anéis em crianças e nas falanges, estes dois elementos poderão ser vistos em representações femininas e de crianças desde o século XV ao XVII. Infelizmente a sua diferenciação é quase impossível, como acontece com os dois elementos coletados nas escavações realizadas na Sinagoga de Castelo de Vide (Figura 2.f, g).

Paralelamente o surgimento de anéis de forma quadrangular com uma pedra na zona central parecem integrar uma tendência joalheira com grande divulgação durante os séculos XVI e XVII, elementos semelhantes surgem em escavações do Edifício das Cavalariças, contudo a pedra que ostentam é em vidro (Figura 2.h). Em várias culturas a produção de adornos através desta matéria siliciosa, foi frequentemente associada à tentativa de imitação de pedras preciosas, paulatinamente vão adquirindo o mesmo valor mágico e simbólico que os elementos que pretendem substituir, o que permitiu o crescente prestígio e importância sociocultural deste material (RODRIGUES, 2001, p. 165).

Esta tentativa de imitação ou substituição através da utilização do vidro poderá ser visualizada num anel proveniente da Igreja de Nossa Senhora da Espe- 
rança do Convento de São Francisco de Castelo de Vide e produzido em liga metálica com vestígios de banho dourado, em ambas as laterais exibe encastrado três elementos redondos em vidro verde claro e ao centro um em vidro transparente (Figura 2.i). Alguns autores apresentam este modelo de adorno como sendo uma produção francesa do século XVII-XVIII. Elementos semelhantes foram descobertos em cobre ou prata, com pedraria semipreciosa e pasta de vidro em Santa Rosa Pensacola (1723-1752), local com forte relação com o comércio francês (DEAGAN, 2002, p. 125). A cronologia apresentada por Kathleen Deagan, para estes anéis poderá ser aplicada no objeto aqui apresentado, pois o sítio arqueológico português só teve um abandono efetivo entre os séculos XVIII-XIX.

Apesar de não ter sido possível encontrar referencias pictóricas ou documentais, foram identificadas três categorias de anéis que devido à sua facilidade de confeção e reprodução vemo-los surgir em contextos com balizas cronológicas muito díspares. Um destes modelos são os anéis com forma de espiral (Figura 2.j), como é o caso dos elementos recolhidos no Castelo de Castelo de Vide, elementos semelhantes surgem noutros sítios arqueológicos balizados entre os séculos XV e XVI. Porém a forma espiralada deste elemento parece ser um modelo com uma intensa divulgação geográfica e cronológica, pois elementos semelhantes apareceram em contextos de escavações romanos no Reino Unido, atribuídas ao século V-VI d.C. (CRUMMY, 1983, p. 48). O The Metropolitan Museum of Art apresenta um anel em ouro com decoração em espiral, porém datado da segunda metade do século VIII-X d.C. e originário de Java (www.metmuseum.org/art), para além destes foi possível identificar um exemplar mais tardio recuperado numa antiga colónia espanhola com ocupação setecentista (DEAGAN, 2002, p. 126). A forma de espiral é um motivo decorativo conhecido desde o Paleolítico Superior, tanto em cerâmicas, pinturas parietais como em objetos de arte móvel. A nível simbólico "(...) a espiral expressa o esforço perpétuo da periferia para alcançar o centro e vice-versa" (GOMES, 2010, p. 394), esta é frequentemente associada a energia, continuidade, eternidade, tempo cíclico e renovação, elementos estes oferecidos pela sua forma fluída e dinâmica. Os elementos aqui apresentados permitem-nos constatar uma difusão e perpetuação deste modelo de anel e amuleto desde pelo menos do século $\mathrm{V}$ ao XVIII.
O segundo modelo anteriormente referido, é uma categoria de anel em que a sua decoração consiste em envolver um fio em torno de um aro (Figura 2. k) e a sua facilidade de confeção reflete a mesma amplitude cronológica, vários exemplares foram recolhidos num ossário do Convento de São Vicente de Fora e nas escavações do Edifício das Cavalariças do Castelo de Castelo de Vide. Por fim o terceiro padrão consiste na composição de três fios metálicos entrelaçados entre si (Figura 2. 1), em território português foi possível identificar nas escavações do Convento de São Vicente de Fora e nos trabalhos da Praça de Armas do Castelo de Castelo de Vide, ambos os locais com ocupação findada por volta do século XVIII. Para estes elementos foi possível localizar um paralelo londrino proveniente de um contexto de século XIV (EGAN \& PRITCHARD, 1991, p. 331). Podemos então pressupor que os dois elementos nacionais estiveram pelo menos em utilização desde o século XIV ao XVIII, esta cronologia tão dilatada só é possível devido à sua fácil produção, pois apenas seria necessário torcer os fios metálicos entre si.

\section{BRINCOS}

A perfuração de orelhas, uma das práticas mais antigas de modificação corporal, permitiu a utilização de brincos como adornos, estes foram utilizados por homens, mulheres e crianças de todas as idades e estratos sociais, podendo ser utilizados um ou mais em cada orelha, produzidos com uma grande diversidade de materiais, formas e tamanhos. Como elemento decorativo estes têm a função de atrair a atenção para o rosto e consequentemente para a pessoa que os utiliza, marcando a sua personalidade, simbolicamente têm a função de abrir os orifícios auditivos para receber os sons exteriores, nutrir e purificar o espírito do seu utilizador. Estes também protegem contra a entrada de energias negativas garantindo um contínuo bem-estar físico, mental e evitam o ataque de espíritos.

No que se refere a brincos, os registos arqueológicos apresentam uma ampla diversidade de modelos, um destes exemplares é um brinco com uma pérola em forma de lágrima, com um pequeno laço ou laça fragmentado numa das pontas e preso a uma argola (Figura 3.a), este é proveniente de um enterramento junto de uma das paredes da Igreja Matriz de Loures. A análise osteológica identificou o inumado como sendo do sexo feminino de idade avançada, os 
materiais recolhidos na mesma camada de enterramento identificaram a sepultura como sendo do século XVII (OLIVEIRA, 2003, pp. 3-7). A morfologia deste objeto evolui dos laços de seda e veludo que suspendiam elementos decorativos nas vestes ou no seu utilizador, posteriormente irão ser produzidos em outros materiais, tais como demonstram os brincos em azeviche e com um laço na parte central recolhidos nas escavações da Fragata Santo António de Taná, naufragada ao largo de Mombaça em 1697 (GIL, TEIXEIRA, 2012, p.48o).

Um brinco de modelo semelhante poderá ser visualizado na pintura Female portrait de Alessandro Bonvicino contemporâneo do brinco aqui apresentado, porém o retrato apresenta o laço em tecido. A utilização de pérolas nos lóbulos não é uma ação casual, estes elementos são uma das matérias preciosas mais antigas conhecidas pelo homem que o fascinaram pela sua diversidade de cores, formas e pela ausência de esforço ou ferramenta para revelar o seu esplendor. Tal como outras matérias primas, também às pérolas estiveram associadas propriedades míticas, curativas e supersticiosas?3.

3. Na mitologia Greco-Romana acreditava-se que a sua formação derivava de lagrimas de deuses e consequentemente é-lhe atribuída uma origem divina, neste sentido não é surpreendente a sua associação com a deusa grega Afrodite e romana Vénus e aos seus mitos de criação, estas associadas à beleza, amor e sedução, o seu nascimento do mar, tal como originalmente descrito pelo poeta grego Hesíodo, fortaleceu a sua associação com as pérolas. Para além desta associação a erudição romana considerava a formação de pérolas como uma transformação de gotas de orvalho, que teriam sido recebidas por conchas marinhas durante as noites de lua cheia, momento este em que estes moluscos emergiam à superfície.

As civilizações orientais não se mantiveram indiferentes à atribuição de propriedades sobrenaturais e curativas às pérolas, sendo frequentemente associadas à perpetuação de juventude, cura de doenças oculares e mentais, antídoto para envenenamento, potencializa força e saúde (ELIADE, 1991, pp. 144-145) Mais tardiamente esta matéria preciosa é integrada na cultura cristã como representativa do amor de Deus, sinónimo de pureza, castidade, inocência, humildade e consequentemente tornam-se um símbolo da Virgem Maria.

Esta associação cristã, mantem-se e perlongou-se por toda a medievalidade e modernidade. Com o crescente culto à Virgem Maria, a adoção de pérolas como sinónimo de pureza, maternidade, consequentemente verificou-se um crescente aumento da sua veneração por gestantes que procuravam obter proteção. Alguns lapidários medievais e renascentistas descrevem as propriedades mágicas e medicinais das
Outro elemento desta categoria de adornos foi recolhido na Igreja de Santa Maria de Sabonha de Alcochete (Figura 3.b), exumado num enterramento datado do século XV, juntamente com uma moeda ilegível e um anel em forma de nó, parece ter sido inspirado num modelo romano em ouro eáguas marinhas patente no Museum of Cycladic Art (www. cycladic.gr), neste elemento podemos visualizar o processo de reavivamento da glória greco-romana, sentido durante a Idade Moderna, estas reminiscências Clássicas irão marcar a joalharia desta cronologia e posterior, o mesmo modelo de brinco poderá ser observado numa representação de século XVIII intitulada Poetry de Marie-Victoire Lemoine.

\section{PULSEIRAS}

Tal como outros objetos de adorno, também as pulseiras e os materiais em que são realizadas integram a categoria de objetos profiláticos que combatem o que não pode ser controlado, o desconhecido, enfermidades e superam o medo da morte, protegendo a pessoa que os ostenta, podendo aparecer isolados ou em combinação com outros elementos com a mesma forma, tais como anéis ou colares.

Devido á sua forma circular relacionada com o sentido de movimento contínuo, sem fim, que aprisiona indefinidamente o mal, daí a sua associação aos mais

pérolas, um destes exemplares é o Lapidario de Afonso X rei de Castela, que apresenta esta matéria como sendo benéfica para "... arte de fisica es muy buena, ca presta mucho a la tremor del corazón y a los que son tristes o medrosos, y a toda enfermedad que venga por melancolía, ca ella limpia la sangre del corazón. ..” "... que ponen en los ojos porque esclarece mucho el viso, esforzando los nervios, y tollendo los vahos, y enjugando la humedad que desciende a ellos." (www.xtal. iqfr.csic.es).

A crença nas propriedades medicinais das pérolas persistiu por toda a Idade Média e Moderna, o cientista Francis Bacon em c.16oo relata a pulverização de pérolas numa mistura de sumo de limão como um elixir de prolongação da vida. A esposa do arquiduque Fernando II da Áustria, c. 1570 elabora um livro onde descreve uma série de curas medicinais, recomendava esmagar pérolas e combiná-las com todo o tipo de produtos de origem animal para a cura de debilidades e doenças femininas (HOLZACH, SCHMIDT-MAPPES, \& GOODMAN, 2013, p. 13).

Nestes séculos as pérolas são utilizadas principalmente pelo seu significado religioso, propriedades mágicas e medicinais, passando a ser um indiciador do nível de riqueza e status social não só nas cortes ibéricas, mas as suas ramificações estendem-se por toda a Europa. 
desprotegidos e à proteção dos pontos mais sensíveis do corpo, pulsos e tornozelos maioritariamente de mulheres e crianças (CRESSIER, 1993, p. 79; SOUSA \& alii, 2018, p. 448; UREÑA, 1997, p. 306). Estes elementos de adorno podem apresentar uma ampla gama cromática, tal como sucede com as suas decorações desde as mais simples, sem decoração, às mais elaboradas.

Outra característica a ter em consideração é o número de pulseiras que cada indivíduo transportava, normalmente mais do que uma no mesmo membro, estas quando chocam com outros objetos ou entre si produzem um ruido característico, que também poderia ter o propósito de afastar o mau olhado.

Neste sentido não é de estranhar que a colocação de cada pulseira formaria parte de um ritual, talvez com a leitura de uma espécie de oração ou formula mágica que protegeria o seu proprietário. Exemplo desta atividade, é uma pulseira em bronze do século XII-XIII, descoberta no Castelo de Allende, localizado em Córdova, esta ainda conserva em cada uma das extremidades, elementos relacionados com o sistema de fecho, apresenta também decoração geométrica, fitomórfica e uma inscrição "La bendición completa y el [¿̇beneficio universal?] [. . . y la prosperidad, la bendición (?) y la generosidad". Apesar desta inscrição estar incompleta, é compreensível o caracter profilático e protetor que a sua epígrafe apresenta (ENAMORADO \& CARMONA, 1999, p. 162).

A simbologia das pulseiras, permanece ressoante até à atualidade, na tradição indiana considera-se que o período de lua de mel de uma mulher termina quando a última bracelete de vidro, que foi posta no dia do casamento se parte, em caso de viuvez, as mesmas seriam despedaçadas em sinal de luto e fim de compromisso. Em função destes fatores a quebra acidental destes adornos é encarado como sinal de mau presságio e de azar.

Exemplo destes elementos é uma pulseira metálica (Figura 4.a) recolhida nos trabalhos realizados no Edifício das cavalariças do Castelo de Castelo de Vide, esta apresenta decoração semelhante a pulseiras representadas por Nicolaes Eliasz Pickenoy ou a pulseiras de vidro recolhidas na Arrochela de Silves (GOMES, 2005, p. 24) e Igreja Matriz de Loures (OLIVEIRA, 2003, pp. 3-7).

Para além destes elementos é de referir os objetos recolhidos no ossário do Convento de São Vicente de Fora (Figura 4.b,c), devido às suas reduzidas dimensões, provavelmente seriam pertencentes a crianças, este tipo de prática ancestral permaneceu em voga até ao século XX. Para além da simbologia destes elementos a quantidade de pulseiras também poderá apresentar um carácter apotropaico.

Esta tipologia de braceletes de vidro são bem conhecidas desde a Antiguidade, sobretudo durante a Idade do Ferro e Período Romano (MEDICI, 2014, p. 505), em contexto moderno português a sua utilização foi comprovada em Alcácer Ceguer numa sepultura datada do século XV, com esqueleto feminino jovem que apresentava uma bracete de vidro em cada braço, e no convento de Santa Clara-a-Velha de Coimbra utilizados durante o século XVII mesmo num contexto em que elementos de adorno e joias seriam expressamente proibidos pelas constituiçõens Gerais da Ordem de Santa Clara (MEDICI, 2014, p. 505).

\section{ELEMENTOS DECORATIVOS}

Nesta categoria de materiais arqueológicos foram apresentados elementos que pela sua morfologia poderiam integrar uma panóplia de funções.

O elemento decorativo (Figura 5.a), à primeira vista poderá aparentar ser um pendente, contudo a decoração semelhante a um camafeu não deveria ser representada na transversal. Um objeto igual foi exumado nas escavações de Alcácer-Ceguer, em contexto de ocupação portuguesa (séculos XV a $\mathrm{XVI}$ ), este objeto ainda conserva um elemento em forma de "s" e decorado com uma cobra (REDMAN, ANZALONE, \& RUBERTONE, 1979, p. 14). Face à visualização deste paralelo, a utilização deste objeto como pendente poderá ser descartada e lava-nos a cogitar a possibilidade de ter sido utilizada como fivela de cinto.

No caso do amuleto em forma de figa (Figura 5.b), claramente foram utilizadas como elemento apotropaico, tanto pela sua forma como pelo seu material. A utilização de figas em azeviche ${ }^{4}$ como elementos de joalharia é muito comum principalmente como amuleto contra o mão olhado, principalmente nos

\footnotetext{
4. A esta matéria foram sendo atribuídas propriedades mágicas e protetoras, bem como medicinais e quiromânticas, sendo de destacar a sua capacidade de afugentar demónios, serpentes e tratar as suas mordeduras, curar dores de dentes, bem como histeria e epilepsia, doenças cardiovasculares, obstruir a inveja, a má sorte, o mau-olhado, etc. Tal como o coral, também esta pedra era considerada potente contra todas as formas de males.
} 
elementos sociais mais vulneráveis, crianças e mulheres. $\mathrm{O}$ aparecimento deste elemento em contexto conventual, figuras estas que remontam à antiguidade pagã, confirmam o estranho casamento da superstição com a religião. A utilização de figas não se cingiu apenas à proteção contra o mau olhado (DEAGAN, 2002, p. 95). O azeviche foi a principal matéria prima para a produção de figas, contudo estas também foram produzidas em coral, vidro, cristal de rocha, metal, concha, âmbar e outros materiais, também poderiam ser empregues para a sua produção. O elemento decorativo com uma águia bicéfala ( $\mathrm{Fi}$ gura 5.c), tal como outros elementos provenientes do local, também não apresenta indicação da estratigrafia onde este foi exumado, contudo foi possível encontrar um objeto semelhante num museu madrileno datado do século XVII. Estes elementos poderão ter sido utilizados como pendente, insígnia militar ou decoração de vestuário pertencente a um membro da família Habsburgo. Elemento semelhante surge representado num retrato de Ana da Áustria, família a que a nova rainha pertencia por parte de pai Maximiliano II e por parte de mãe, Maria da Áustria.

O corno metálico (Figura 5.c) recolhido em Castelo de Vide apresenta um pequeno orifício para aplicar um elemento de suspensão. Desde a antiguidade o corno foi associado a força, poder, fertilidade e vitalidade (AMATO, 2018, p. 53) e tal como outros elementos apotropaicos estes também são utilizados pelos grupos sociais mais frágeis, razão pela qual aparecem frequentemente em representações de mulheres e crianças.

\section{CONSIDERAÇÕES FINAIS}

Os objetos em estudo demonstram a sua mais íntima ligação com a vida humana evocando datas, acontecimentos, tristezas ou alegrias independentemente dos materiais empregues na sua produção serem dispendiosos ou vulgares, face a estes fatores, as joias e elementos de adorno são sempre um reflexo do gosto e vivências de um indivíduo, inserido num grupo e sociedade integrada no seu tempo e espaço. Como foi possível percecionar os adornos foram utilizados como elementos de beleza, de enfeite, de proteção, medicinal na forma de amuletos, pertença social, enquanto elemento identificativo, estado civil, demonstração e procura de status social, uso funcional enquanto elemento participativo em ves- timentas e por fim exibição e armazenamento de riqueza. Assim este conjunto evidencia a diversidade de modelos e singularidades constituindo um interessante e eloquente testemunho de um passado que muitas vezes só eles podem decifrar.

A chegada da armada de Vasco da Gama à Índia permitiu a ligação entre a Europa e os principais centros de produção e extração de matérias preciosas e semipreciosas. Este internacionalismo comercial adjunto à invenção da imprensa, a requisição de artesãos para trabalhar em capitais estrangeiras, movimentação de princesas, dotes e respetivos séquitos que continuaram a usar e a produzir os seus estilos de adornos, mas abrindo horizontes face às novas realidades e influências do seu envolvente, geraram uma maior profusão e circulação de modelos, formas, através de gravuras e desenhos por toda a Europa.

Esta nova realidade promoveu a diversificação e aumentou a panóplia de materiais e tipologias ao longo do avanço dos séculos, os elementos de adorno devido à sua perecibilidade e fragilidade surgem em contexto arqueológico de forma reduzida, em comparação com outros materiais. Para além deste fator os elementos em estudo, frequentemente encontram-se em estado de conservação deficitário o que dificulta em muito a sua análise e estudo. A maioria destes não sendo alvo de estudos sistemáticos acaba em depósitos ou reservas, apenas inventariados de forma sumária e na maioria das vezes sem informação acerca do seu local de exumação, acabando por nunca serem apresentados, publicados, isoladamente ou em bibliografia especifica sobre os mesmos.

A investigação acerca de elementos de adornos arqueológicos em contextos modernos encontra-se muito incipiente em Portugal, razão pela qual dificultou a compreensão e procura de paralelos arqueológicos portugueses para os elementos estudados. Contudo a análise de materiais realizada, possibilitou demonstrar a grande profusão de elementos considerados como "joias populares" ou de caracter quotidiano, elementos estes que dificilmente se vem representados, ao contrário dos seus semelhantes em matérias preciosas.

Assim é possível compreender que a joia difunde-se, espalha-se e torna-se objeto de desejo e de adorno, vaidade, enfeite e embeleza de quem as coloca, "democratizando-se" o seu uso. Contudo é de ter em atenção que as peças de maior valor dificilmente aparecem no registo arqueológico. pois face ao seu elevado valor monetário facilmente poderiam ser 
readaptadas e reutilizadas continuamente por várias gerações.

Por fim concluímos que os materiais estudados permitiram compreender a profusão de joias cada vez mais diversificadas a nível estilístico e de material, o que permitiu a utilização destes por boa parte da sociedade, assim como compreender as redes de interações comerciais e simbologias.

\section{BIBLIOGRAFIA}

AMATO, M. (2018) - Os simbolismos dos animais com chifres em bestiários ingleses. Lisboa: Dissertação de Mestrado em História Medieval apresentada à Faculdade de Ciências Sociais e Humanas da Universidade Nova de Lisboa (Texto Policopiado).

ASHBY, S. (2005) - Bone and antler combs: towards a methodology for the understanding of trade and identity in Viking Age England and Scotland. In H. LUIK, A. M. CHOYKE, C. E. BATEY, \& L. LOUGAS (ed.), From Hooves to Horns, from Mollusc to Mammoth: Manufacture and Use of Bone Artefacts from Prehistoric Times to the Present. Muinasaja Teadus (pp. 255-262.). Tallinn: University of Tartu.

CORREIA, M. (2005) - Santa Maria de Sabonha - São Francisco (Alcochete) Relatório arqueológico. Alcochete: (Texto Policopiado).

CRESSIER, P. (1993) - Humildes joyas: pulseras de vidrio en una casa andalusí de Senés (Almería). Revista del Celtro de Estudios Históricos de Granada y su Reino nº 7, pp. 67-84.

CRUMMY, N. (1983) - Colchester Archaeological Report 2: The Roman small finds from excavations in Colchester 1971-9. Essex: Colchester Archaeological Trust.

DEAGAN, K. (2002) - Artifacts of the Spanish Colonies of Florida and the Caribbean, 1500-1800: Portable Personal Possessions v. 2. Washington \& London: Smithsonian Institution Press, pp. 63-77.

EGAN, G., \& PRITCHARD, F. (1991). Dress Accessories, c. 1150 - c. 1450 (Medieval Finds from Excavations in London). London: Boydell Press.

ELIADE, M. (1991) - Images and Symbols: Studies in Religious Symbolism. Princeton: Princeton University Press.

ENAMORADO, V., \& CARMONA, R. (1999) - Una pulsera epigráfica de época almohade hallada en el castillo de Allende (Zuheros, Córdoba). Antiquitas nº 10, pp. 161-166.

GIL, L., \& TEIXEIRA, A. (2012) - Cada botão sua casaca. Indumentária recuperada nas escavações arqueológicas da fragata Santo António de Taná, naufragada em Mombaça em 1697. in Velhos e Novos Mundos, Estudos de Arqueologia Moderna, pp. 671-682.

GOMES, M. V (2010) - Arte rupestre do Vale do tejo: um ciclo artístico-cultural Pré e Proto-Histórico. Lisboa: Dissertação de Doutoramento em História, especialização em Arqueologia, apresentada à Faculdade de Ciências Sociais e Humanas de Lisboa.

GOMES, M.; GOMES, R.; \& GONÇALVES, J. (2017) - Objetos produzidos em matérias duras de origem animal, do convento de Santana de Lisboa. I Encontro de Arqueologia de Lisboa: Uma Cidade em Escavação, pp. 84-105.

GOMES, R. V. (2006) - Silves (Xelb), uma cidade do Gharb Al-Andalus: a zona da Arrochela, espaços e quotidianos. Lisboa: Instituto de Gestão do Património Arquitetónico e Arqueológico.

HOLZACH, C.; SCHMIDT-MAPPES, I.; \& GOODMAN, S. (2013) - Schaumgeboren und sagenumwoben - Schmuck aus Perlen/Angels Tears or Gems oft he Ocean-Pearls in the History of Jewellery. Pforzheim: Schmuckmuseum.

LIORET, R., \& SANCHIS, S. (1999) - Joyas y sociedad. Estudis: Revista de História Moderna, pp. 7-24.

LOUREIRO, N.; \& TORRÃO, M. (2008) - Homens e tartarugas marinhas. Seis séculos de história e histórias nas ilhas de Cabo Verde. Anais de História de Além-Mar vol 9, pp. 37-78.

MEDICI, T. (2014) - O vidro tardomedieval e moderno em Portugal (séculos XIV-XVII). O contributo da arqueologia. Coimbra: Dissertação de Doutoramento apresentada à Faculdade de Letras da Universidade de Coimbra (Texto Policopiado).

REDMAN, C.; ANZALONE, R.; \& RUBERTONE, P. (1979) - Medieval Archaeology at Qsar es-Seghir, Morocco. Journal of Field Archaeology, vol. 6, $n^{\circ}$ 1, pp. 1-16.

RODRIGUES, M. (2001) - Actas das Sessões IV Colóquio Temático: As Escalas de Lisboa Morfologias População Identidades. A Presença das contas de vidro como elemento de identidade do Africano no passado histórico e cultural de Lisboa Dos meados do século XV ao terramoto de 1755, pp. 161-208.

ROOP, E. (2011) - History and Meaning of symbolic rings - a creative project. Indiana: Dissertação de Mestrado em Artes apresentada à Universidade de Ball State Universitu Muncie (Texto Policopiado).

SANTOS, S. (2010) - Reabilitação e Reconversão do Convento de S. Francisco em Castelo de Vide Acompanhamento arqueológico - Relatório Final. Archeo'Estudos, Investigação Arqueológica: Castelo de Vide.

SESSIN, S. (2014) - Gems in Renaissance Material Culture. London: Dissertação de Mestrado apresentada à University of London (texto policopiado).

SOUSA, J.; LACAMBRA, M.; JIMÉNEZ, A.; PERNÍA, M.; \& GÓMEZ, J. (2018) - Elementos de adorno y amuletos de pasta vítre recuperados en el yacimento arqueológico de "La Mezquita”, Cadalso de los vidrios (Madrid). III Jornadas Jóvens Investigadores en Arqueologia, 445-453. 
TAIT, H. (1996) - Seven thousand years of jewellery. London: British Museum Press.

UREÑA, A. (1997) - Un conjunto de pulseras de vidrio hallado en la excavación del Hospital de San Andrés (Escalona, Toledo). Boletín de Arqueología Medieval nº 11, pp. 293-312.

www.metmuseum.org (consultado a 24/05/2019)

www.xtal.iqfr.csic.es (consultado a 24/05/2019)

a)

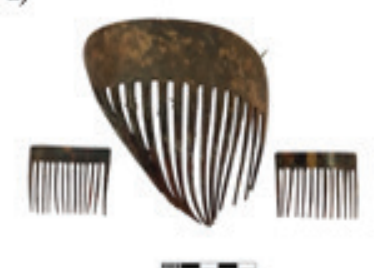

d)

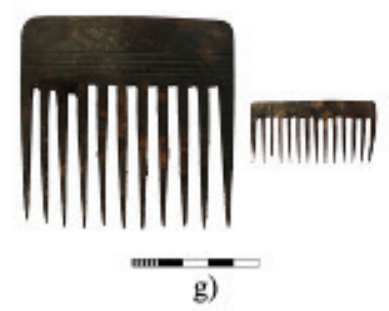

b)

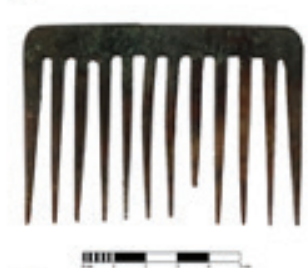

e)

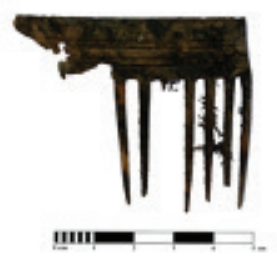

h) c)

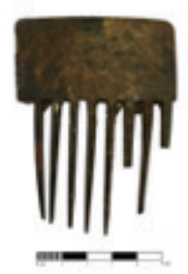

f)

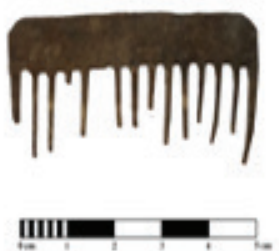

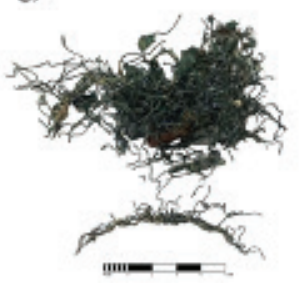

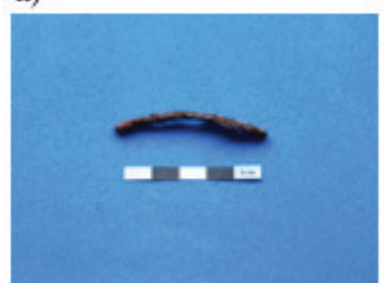

Figura 1-a)b) c) d) e) f) Pentes ou travessas, casca de tartaruga, Igreja de Nossa Senhora da Esperança do Convento de São Francisco de Castelo de Vide (Autor: Jéssica Iglésias). g) Toucado de cabelo, liga metálica, Igreja de Santa Maria de Sabonha (Alcochete) (Autor: Jéssica Iglésias). h) Bandolete, liga metálica Igreja do Convento de Nossa Senhora da Conceição de Almodôvar (Autor: Sara Luz). 
a)

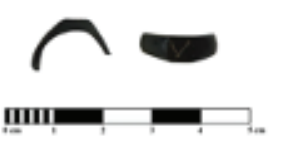

e)

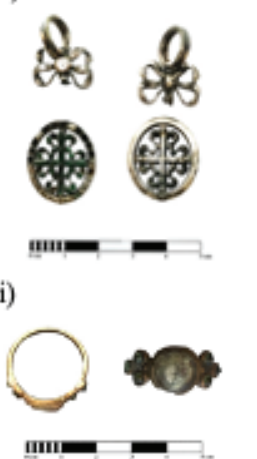

b)

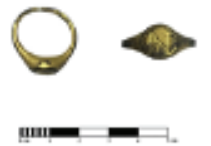

f)

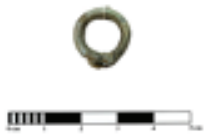

j)

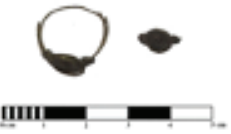

c)

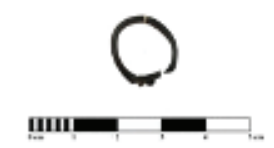

g)

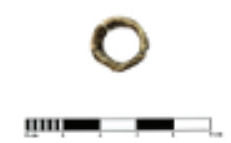

k)

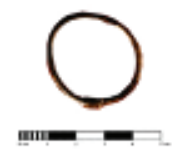

d)

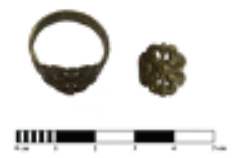

h)

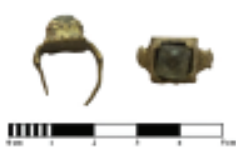

1)

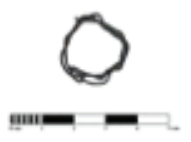

Figura 2 - a) Anel, azeviche, Edifício das Cavalariças do Castelo de Castelo de Vide (Autor: Jéssica Iglésias). b) Anel, liga metálica, Castelo de Torres Vedras (Autor: Jéssica Iglésias). c) Anel, pasta de vidro de cor negra, Edifício das Cavalariças do Castelo de Castelo de Vide (Autor: Jéssica Iglésias). d) Anel, liga metálica, Sinagoga de Castelo de Vide (Autor: Jéssica Iglésias). e) Pendente, liga metálica, Igreja de Nossa Senhora da Esperança do Convento de São Francisco de Castelo de Vide (Autor: Jéssica Iglésias). f) g) Anéis, vidro negro, Sinagoga de Castelo de Vide (Autor: Jéssica Iglésias). h) Anel, liga metálica, Edifício das Cavalariças do Castelo de Castelo de Vide (Autor: Jéssica Iglésias). i) Anel, liga metálica, Igreja de Nossa Senhora da Esperança do Convento de São Francisco de Castelo de Vide (Autor: Jéssica Iglésias). j) Anel, liga metálica, Sinagoga de Castelo de Vide (Autor: Jéssica Iglésias). k) Anel, liga metálica, Convento de São Vicente de Fora (Autor: Jéssica Iglésias). 1) Anel, liga metálica, Convento de São Vicente de Fora (Autor: Jéssica Iglésias).

a)
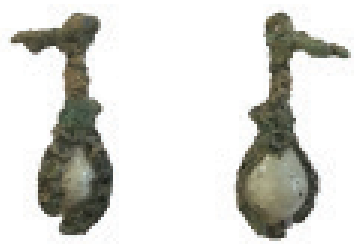

IIII

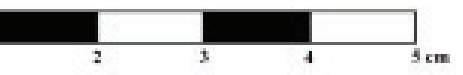

b)

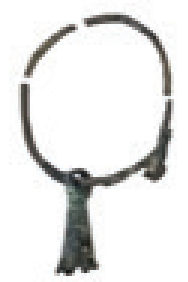

\section{IIIII}

Figura 3-a) Brinco, liga metálica e pérola, Igreja Matriz de Loures (Autor: Jéssica Iglésias). b) Brinco, liga metálica, Igreja de Santa Maria de Sabonha (Alcochete) (Autor: Jéssica Iglésias). 

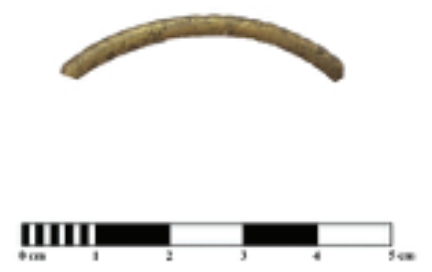

b)

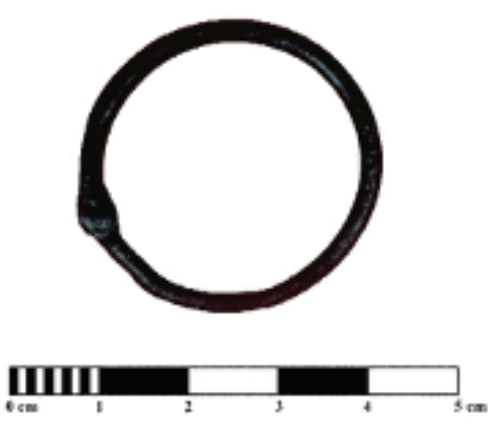

c)

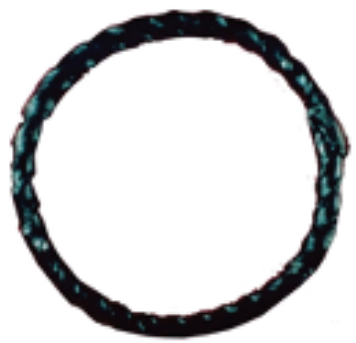

IIIII

Figura 4 - a) Pulseira, liga metálica, Edifício das cavalariças do Castelo de Castelo de Vide (Autor: Jéssica Iglésias). b) c) Pulseiras, vidro negro, Convento de São Vicente de Fora (Autor: Jéssica Iglésias).

a)

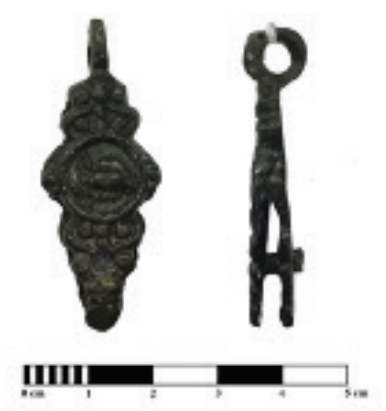

c)

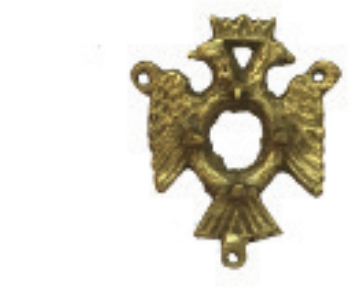

ШII b)

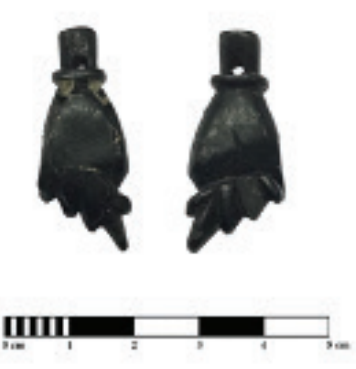

d)

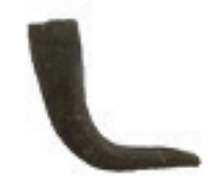

IIIIII

Figura 5-a) Elemento decorativo, liga metálica, Castelo de Torres Vedras (Autor: Jéssica Iglésias). b) Figa, azeviche, Castelo de Torres Vedras (Autor: Jéssica Iglésias). c) Decoração de vestuário, liga metálica, Edifício das cavalariças do Castelo de Castelo de Vide (Autor: Jéssica Iglésias). d) Corno, liga metálica, Praça de Armas do Castelo de Castelo de Vide (Autor: Jéssica Iglésias). 



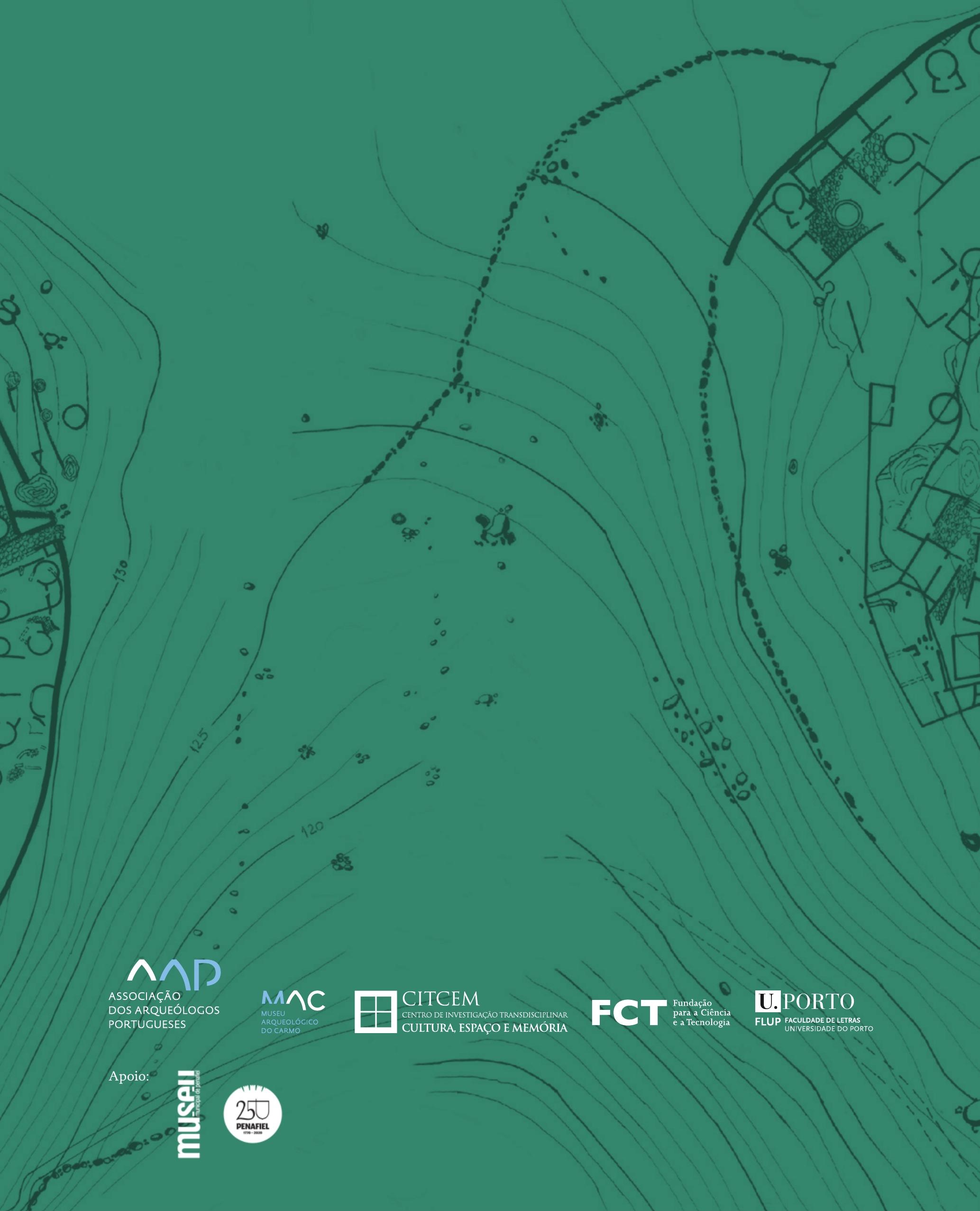

